\title{
COST VOLUME PROFIT ANALYSIS AND PROFIT PLANNING IN MANUFACTURING SMES IN NIGERIA
}

\author{
Kenneth Enoch Okpala ${ }^{1}$ and Chimsunum Osanebi ${ }^{2}$ \\ ${ }^{1}$ Department of Accounting, Faculty of Management Sciences, \\ Redeemer's University, Nigeria \\ E-mail: enocharticles@gmail.com \\ ${ }^{2}$ Department of Management, Faculty of Management Sciences, \\ University of Nigeria, Enugu Campus, Nigeria \\ E-mail: excellchim@gmail.com
}

\begin{abstract}
The manufacturing SMEs encounter many problems, one of which is the inability to earn a sustainable profit for continuity. Inadequate profitability is one the factors responsible for the early death of SMEs in Sub Sahara, Africa. This study examined the usage of the cost volume profit technique on profit planning in manufacturing SMEs as a means to solve the problem. A cross sectional survey research design was adopted, and the study sample population from snowballing consisted of 50 manufacturing SMEs with 1048 senior staff. A questionnaire was used to elicit the respondents' opinions, and 714 useable copies of the survey were returned. Descriptive statistics, Pearson product-moment correlation, and Regression analysis methods were used for data analysis. The study concluded that cost volume profit analysis has a positive and statistically significant impact on profit planning $(\beta=.645, P=.00<.05)$. The study recommends that the management of manufacturing SMEs should employ and retain high-caliber accountants and restructure their management team for effectiveness. The decisionmaking process should be streamlined for planning efficiency, and top management should support the cost volume profit analysis model to aid adequate implementation and results.
\end{abstract}

Keywords: cost volume profit analysis, break-even point, profit planning, manufacturing SMEs, Nigeria

\section{ARTICLE INFO}

\section{Article History:}

Received: 28 April 2020

Accepted: 14 July 2020

Published: 31 August 2020 


\section{INTRODUCTION}

The financial objective of most business ventures is to ensure a surplus position over the investment made in the undertaking and to increase the net worth of the organization (Akinsulire, 2017). Although some organizations may pursue other objectives, most stakeholders prefer profitmaking goals on the ground that only firms with adequate profit survive the competition and have access to new funds (Adeniji, 2017). Sufficient profitability enables a firm to reward capital providers and create further wealth through reinvestment of reserves (Oyerogba, Solomon, Olaleye, \& Adesina, 2014). To achieve an optimal profit level, the firm must properly plan to enable managers to forecast future profitability (Adeniji, 2017). In business management, planning encourages early and adequate preparation to avert any anticipated problem and to attain the set goals. Also, it aids performance evaluation and analysis of variance to redirect management actions (Aremu \& Adeyemi, 2011; Okpala, Adegbola, \& Afolabi, 2018). Poor planning may negatively affect management decisions and profitability of an organization (Lucey, 2003; Abdullahi, 2015). Oyerogba et al. (2014) stated that the chain of the effect of poor planning includes the establishment of a wrong target leading to adverse variance between budget and actual activity, and the inability to achieve the envisaged bottom-line. Therefore, planning entails the use of appropriate financial and management models, such as cost volume profit analysis technique.

The CVPA model helps managers in understanding the inherent association among cost, sales volume, and profit components of a product. It also assists in an accurate projection of the future business turnout (Abdullahi, Suleiman, Mukhtar, \& Musa, 2017). Management decisions based on CVPA may result in the achievement of the desired level of profit and identification of the margin of operational safety in an organization (Jhigan \& Stephen, 2007). However, Ihemeje, Okereafor, and Ogungbangbe (2015) noted that the major problem encountered by manufacturing firms in the use of management accounting models for planning and decision making was tied to managerial incompetence. According to Aremu and Adeyemi (2011), a considerable percentage of the Nigerian SMEs do not survive the initial five years of the establishment while others shut down between the sixth and tenth years of existence. Only about five to ten percent continue in business and grow to maturity. 
The premature death of SMEs has been traced primarily to the inability to generate adequate revenue to cover its operating costs and make a sustainable profit (Abdullahi et al., 2017). Other factors inhibiting the financial performance of the SMEs include absence or weak application of management accounting techniques to aid decision process, lack of funds to operate and compete favourably. The non-availability of modern production technologies, inadequate infrastructure, and reduced customer patronage were also some of the problems encountered. All these issues have weakened the ability of the products produced in these manufacturing SMEs to withstand the keen competition with foreign products, which has further compounded profit-making capacity (Agwu, 2014; Abdullahi, 2015; Ihemeje et al., 2015; Abdullahi et al., 2017). According to Adesina, IkhuOmoregbe, and Aboaba (2015), the major impediment of profit-making in the manufacturing sector has been the absence of the use of management accounting methods, as well as staff and management incompetence. Abdullahi et al. (2017) noted that the inability of some management accountants to use appropriate tools as responsible for the predicaments experienced in the manufacturing sector.

Based on the preceding assertions, the questions that this study attempted to provide answers in the context of manufacturing SMEs were: (i) What is the effect of appropriate accountants' qualifications and experience on profit planning? (ii) How does the management decision-making process affect profit planning? (iii) To what extent has the top management support of the CVPA technique affected profit planning? To the best of these researchers' knowledge, no study was conducted on the direct relationship between the CVPA model and profit planning in manufacturing SMEs' in terms of qualification and experience of the accountants, decision-making process, and the top management support for the CVPA model. Omission of research in this direction has prevented a conclusion on the strength of the association between the variables. Therefore, further research is needed to bridge the gap in manufacturing SMEs in Nigeria. The general objective of this study was to examine the effect of the CVPA technique on profit planning in manufacturing SMEs in Nigeria. This goal would enable the researcher to provide management suggestions for future achievement. The broad objective of the study was attained by pursuing the following secondary goals: to assess the effect of accountants' qualifications and experience on profit planning, to evaluate the decision-making process on 
profit planning, and to examine the effect of top management support of CVP analysis application on profit planning in Nigerian manufacturing SMEs.

This study focussed on the CVP analysis technique and profit planning within the context of manufacturing SMEs in Nigeria, and data collected were limited to the senior staff of the subsector. All microenterprises, other manufacturing companies, and SMEs outside the manufacturing sector within and outside Nigeria were excluded. Due to the large number of manufacturing SMEs in Nigeria, data collection was limited to SMEs in the Lagos state as the business hub of Nigeria. The primary justification for this research was to provide practical evidence on the effect of CVP analysis technique on profit planning as a means of resolving the profitability problem in manufacturing SME's

The decision to study these manufacturing SMEs was first based on the inadequate profitability, the early death of the firms, and its grave adverse economic implications in emerging economies. Secondly, the importance of the subsector in developing economies to attain government macroeconomic objectives, especially in nations with low industrial activities. This study will close the existing identified gaps and contribute to the literature. The result obtained would address the research objective to help the management of the manufacturing SMEs to plan, attain the desired profit level, and survive competition. Investors and scholars conducting further studies in this area would also benefit.

\section{REVIEW OF LITERATURE}

Organizations in the course of planning, set-up activities required to achieve the desired goals. Such a process involves a list of steps with details of the timing and resources needed to create and maintain the envisaged level of performance and the consequential result. The CVP analysis technique measures the impact of varying levels of costs and volume on the operating profit to determine the BEP at different sales volumes and cost structures. This is useful for managers making short-term economic decisions. The employment of CVPA is based on its ability to forecast future earnings at different levels of activity. Jhigan and Stephen (2007) described the model as a vital tool used for determining the practical application of cost function. 
It assists managers to examine the relationship between sales and cost components systematically (Chow, 1998; Glautier, Morris, \& Underdown, 2011). CVPA is also used to appraise the financial consequence of a wide range of strategic and operational decisions, especially for short-term profit planning and assessment of the margin of safety (Clancy \& Madison, 1997; Stefan, 2012; Abdullahi, 2015).

Costs which represents expenditure incurred in line with a defined objective for an economic benefit are categorizes into fixed and variables under CVPA as a matter of assumption. While the variable costs fluctuate with changes in the volume of output, the fixed costs remain constant within a relevant range (Stefan, 2012). The variable cost is equal to zero, where no product is manufactured or sold, but the fixed cost is higher than zero. This scenario implies that contribution is maximized to cover the fixed cost, where the selling price per unit is higher than the variable cost per unit (Lucey, 2003). Some costs are hybrid - semi-fixed or semi-variable and must be separated into fixed and variable components before the cost volume profit is analyzed (Adeniji, 2017). The production and sales volume measure the units of a firm's product manufactured and sold within a period (Georgiev, 2014). The application of the CVPA technique effectiveness is seen in touching virtually everything that managers do (Obeta, 2008). The concept of CVPA is mostly employed to ensure profitability of the companies.

\section{The Break-even-point (BEP) Analysis}

The Break-even-point (BEP) analysis is essential to management as it involves the determination of a situation where neither profit nor loss is made. The sales at BEP in quantity and value would enable manufacturers to answer questions such as: what is the minimum sales to earn a contribution to cover the company expense and make a profit, what is the margin at which it is safe to operate? The knowledge of the BEP analysis ensures that the management understands when the company would be in the loss or profit region and the appropriate action to be taken to redirect the company affairs (Chand, 2015; Abdullahi et al., 2017). The CVPA concept is tied to economies of production and management accounting, with divergence views leading to two schools of thought (Ndaliman \& Suleiman, 2011). These views are as follows: 


\section{The Economist CVPA Model}

The economist cost volume profit analysis model was founded on the phenomenon of diminishing marginal productivity. According to Ndaliman and Suleiman (2011), the assumptions of the model include: (i) A firm can only increase the quantities of goods sold by reducing the selling price per unit. The expected increase in the quantity sold triggered-off by a drop in selling price per unit may be responsible for the sharp rise in the total revenue line and the eventual fall. (ii) Total revenue does not increase uniformly with sales volume, (iii) The behaviour of the cost line affects the variation in the cost function, which implies that fixed costs may not be constant over all the activity levels. The variable cost would drop at first, due to increasing physical products per unit of input and would ultimately increase after the point of decreasing-average return has been attained (Drury, 2008). Therefore, the cost line would be on a straight-line on the first instance and later a curvilinear shape. The effect of cost behaviour under the economist model is responsible for at least two BEPs. Figure 1 illustrates the economist's model of cost volume profit analysis.

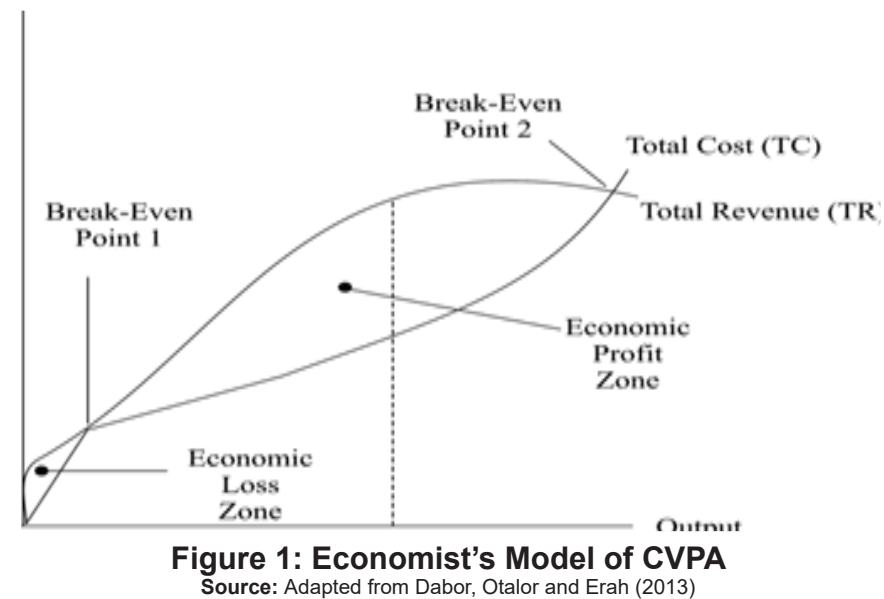

\section{Accountants CVPA Model}

The accountant cost volume profit analysis model assumes that variable cost and selling price per unit is constant, leading to a linear relationship between the total revenue and total cost, irrespective of changes in volume. 
The consequence of this linear relationship is a single breakeven point and the wider profit area as the sales volume increases. Other assumptions include (i) All variables remain constant, except volume, (ii) Only one product is produced. Where there are multiple products, they are sold in the same proportions, (iii) Profit is calculated using marginal costing while fixed costs are treated as a period cost rather than the product cost, (iv) Costs are accurately divided into fixed and variable elements. Semi-variable cost is separated using appropriate techniques, (v) The BEP analysis applies only to the relevant range and does not apply to sales volume outside the envisaged boundaries. In the accountant model, increasing production efficiency and changing sales price levels are not considered. The accountant's model is graphically presented in Figure 2:

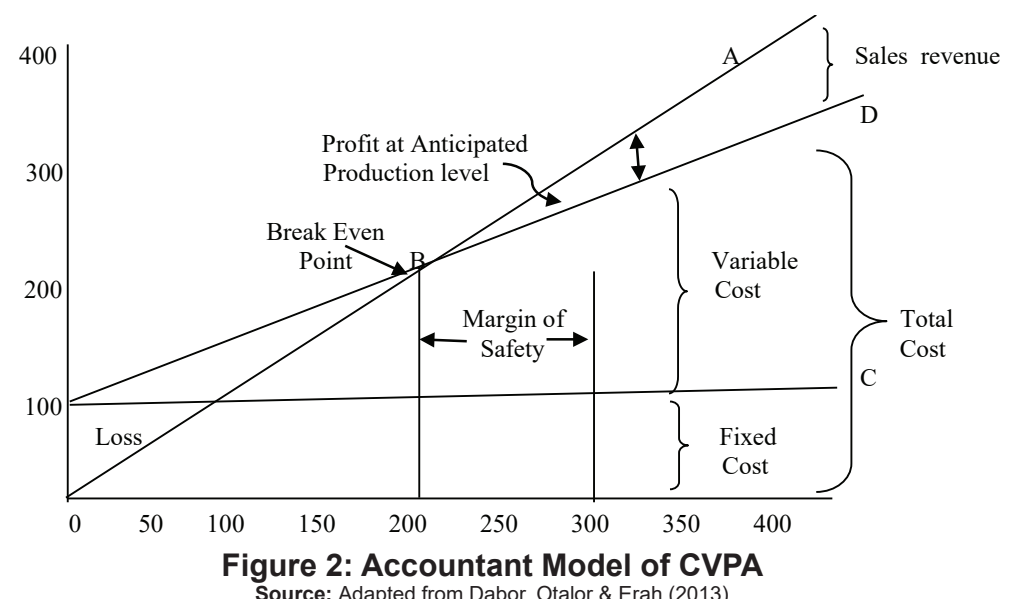

The profit-volume graph method can also be used to illustrate the relationship between the fluctuations in volume, as represented in Figures 3. 


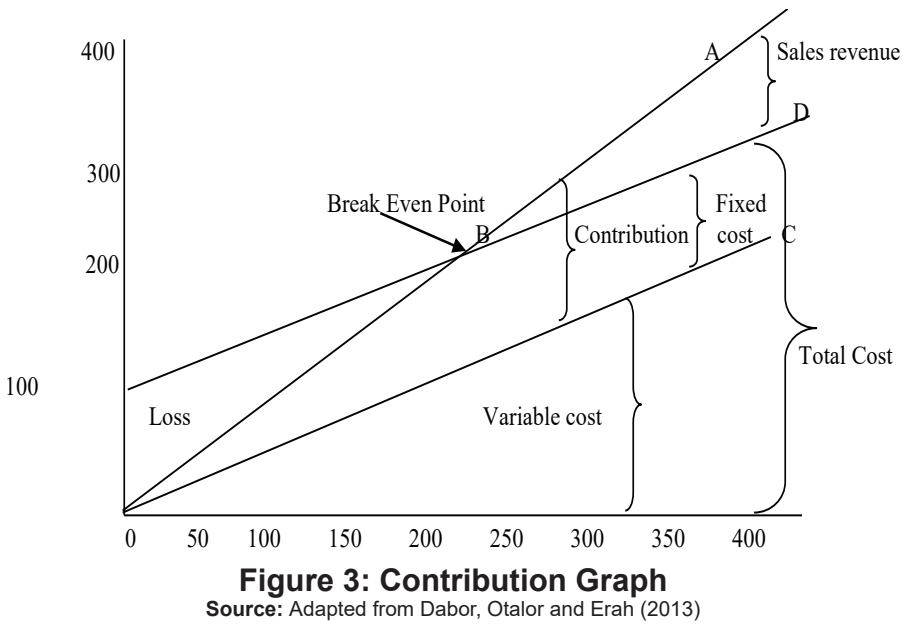

Apart from the graphical representation of breakeven point analysis, the model can be expressed in a mathematical form (Lucey, 2003). The Break-even point value in Naira $=$ Total fixed cost/Contribution margin ratio while $\mathrm{BEP}$ in units $=$ Total fixed cost $/$ Contribution margin. Managers can also use the method to deduce future sales value and in units needed to attain the desired profit level. The desired profit level in Naira = Total fixed cost $/$ Contribution margin ratio while in units $=$ Total fixed cost/Contribution margin ratio. The Contribution margin ratio is calculated as the contribution per unit over sales per unit. The total contribution is described as the total sales revenue less total variable cost. It represents the amount that a product contributed towards the recovery of total fixed costs and to generate profit (Kodjo, 2004). The contribution margin is a key concept in management accounting. It helps managers make the following decisions: (i) To determine the sales at Break-even point as well as the margin of safety. (ii) Whether or not to discontinue a product line. (iii) Whether to change the price of a product or maintain the existing one. (iv) To choose between alternative routes of product. (iv) To make or buy a product or component. (v) To shut down an unprofitable department or unit. And (vi) to allocate limiting factors (Nwachukwu, 2004; Etges, Calegari, Rhoden, \& Cortimiglia, 2016). 


\section{The Margin of Safety}

The margin of safety is the actual total sales minus sales at the breakeven point. It is vital in deciding at what level of production and sales should a firm operate to be safe. The margin of safety may be extended through (i) An increase in selling price where the product demand is inelastic. (ii) Produce up to full plant capacity if the company has extra capacity unutilized. (iii) Reduce the selling price where the product demand is elastic. (iv) Minimize production costs if possible. Where multiple products are sold, the ones with a higher contribution may compensate the ones with a lower contribution per unit (Kodjo, 2004; Hilton, Maher, \& Selto, 2004). Break-even-point analysis has various limitations, but despite that, the method has a high place in financial management (Obeta, 2008; Alnasser, Shaban, \& Al-Zubi, 2014).

\section{Overview of Nigerian Manufacturing SMEs}

The manufacturing SMEs is a term used when separating companies within the category of a small and medium production outfit scope from the larger manufacturing organizations (Asah, Fatoki, \& Rungani, 2015; Makate, Makate, Siziba, \& Sadomba, 2019). A manufacturing SME is an independent firm engaged in the production of goods, whose definition is tied to the number of the employees, annual turnover, and the fixed assets base (Rijkers, Arouri, Freund, \& Nucifora, 2014; Adeniji, 2017). The Central Bank of Nigeria described an SME in Nigeria as a business with eleven to one hundred (11-300) employees, whose turnover is in the region of five hundred thousand naira $(=\mathrm{N}=500,000)$, and its assets base excluding landed property between five to five hundred million naira $(=\mathrm{N}=5 \mathrm{~m}-500 \mathrm{~m})$. This definition may be different in other countries, as SME businesses are conducted in different economies with varied legal boundaries.

In Nigeria, due to crude oil mining and production in the past, full attention was not paid to the small and medium-sized manufacturing firms, which was the reason for the inconsequential contributions of subsector to the national GDP (Egbulonu \& Duru, 2018). The study conducted by the International Finance Corporation (IFC) on SMEs indicated that in Nigeria, $96 \%$ of companies fall within the SMEs category operating in various subsectors in comparison with $53 \%$ and $65 \%$ in the USA and 
Europe respectively (Agwu, 2014; Asikhia, 2016). The subsector has been recognized as the principal source of entrepreneurial and industrial development, job and wealth creation, and poverty alleviation (Okpala, 2012; Eniola \& Ektebang, 2014). Ayozie and Farayola (2005) stated that various governments have shifted attention to manufacturing SMEs to solve their economic development and social problems (Islam, Khan, Obaidullah, \& Alam, 2011). As of 2019, Nigerian SMEs account for $90 \%$ of the manufacturing sector and contributed about $50 \%$ of the industrial jobs and $48 \%$ to GDP (Ogunode, Abereola, \& Oloyede, 2020).

The survival and profitability of the manufacturing SMEs are crucial to all stakeholders in any nation (Kadiri, 2012). Therefore, planning to achieve the desired profit level should be encouraged. Such planning includes the use of different financial management models, one of which is the use of cost volume profit analysis to evaluate the relationships among sales, cost and profit component of a product (Kee, 2007). The management uses information from data analysis to set the targeted profit level to be achieved, formulate strategies for making them and provide necessary direction and facilities to implement the chosen scheme (Jhigan \& Stephen, 2007). In manufacturing SMEs, profit planning is an integral part of the commercial plan structure and important for earning the objective of the business (Glautier et al., 2011).

\section{Theoretical Review}

The innovations theory of profit states that profit from commercial undertakings might emanate from the innovation successfully introduced by the entrepreneur. This theory was propounded in 1934 by Joseph Alois Schumpeter, who noted that the core occupation of an entrepreneur/ management is championing innovations within the economy, and their reward is profit. Schumpeter described innovation as an inclusive concept involving a new strategy implemented by an entrepreneur to minimize production cost or increase product demand (Schumpeter, 1934). There are two types of innovations, namely the first and second. The first class of modernisms aims at minimizing the cost of production through a new technique, acquisition of modern machinery, or adoption of a better production process. It also entails the discovery of either different sources of raw materials, a new or improved method of planning and organizing the 
business. The introduction of a new product, making changes in a product design/package, adopting a superior method of planning, advertising, or finding new markets for the product, is regarded as the second type of innovation. The purpose of the second innovation is to increase product demand. Penrose, in 1959, reinforced Schumpeter's innovations theory of profits. Although, he was only interested in the second part, which involved productive research and original creativity rather than coordination, exchange, and market power (Penrose, 1959). This theory is relevant to this research work because adoption of management accounting models can boost production, sales and consequential profits (Schumpeter, 1934).

\section{Empirical Review}

Previous empirical studies on the practical applications of CVPA to aid strategic, tactical, and operational management decision processes in manufacturing industries were conducted to enhance managerial efficiency in the sector (Dabor, Otalor, \& Erah, 2013; Lulaj \& Iseni, 2018). CVPA provides management with information to make effective decisions (Obeta, 2008). Ihemeje et al. (2015) conducted a study on CVPA and manufacturers' decision-making in Nigeria. The study concluded that the model is a wellconsidered decision-making tool in manufacturing firms. Accordingly, Dabor et al. (2013) found that the CVPA is useful in making a short-run decision, although the model has several unrealistic norms. These findings are in line with the report of Kavitha (2018). Lulaj and Iseni (2018) who studied cost-volume-profit analysis and planning and making decisions in the business environment. The results concluded that the technique has a positive effect on determination of cost and sales volume and consequential profit in the manufacturing business environment. This result indicated that cost volume profit analysis contributes to the growth of profitability. Adesina, Ikhu-Omoregbe, and Kehinde (2015) researched the impact of accounting information on profit planning. The findings concluded that accounting information has a positive and significant effect on profitability of manufacturing firm. Alnasser et al. (2014) note that the application of $\mathrm{BEP}$ has a significant relationship with planning and decision making in Jordanian companies. This study agreed with the report of Georgiev (2014), who concluded that the result generated from the cost-volume-profit analysis has a significant effect on profitability of Bulgarian hotels. Okpala et al. (2018) examined the impact of short and long term management accounting 
information systems on effective business decisions of quoted Fast-moving consumers' goods manufacturing firms in Nigeria. The study concluded that management accounting information system has a significant impact on effective business decision.

\section{HYPOTHESES DEVELOPMENT}

To the best of this researcher's knowledge, the effect of cost volume profit analysis on profit planning in manufacturing SMEs have not been measured in terms of accountants' qualifications and experience, management decision-making process, and top management support as the proxies of the independent variable in the context of manufacturing SMEs. This omission has created gaps in the literature and needs to be studied. Therefore, the following null hypotheses were proposed to test the relationship between the variables and contribute to the body of knowledge.

The employment of qualified and experienced management accountants with knowledge of cost volume profit analysis is assumed to affect the production of information upon which profit can be planned to attain the target. The AQE was measured by educational qualification, professional certification, years of experience, and knowledge of the CVPA model. Due to the absence of studies and results to draw a realistic conclusion on the relationship between AQE and pp1, sub-hypothesis 1 was proposed.

$\mathbf{H}_{1}$ : Accountants' qualifications and experience have no significant effect on profit planning.

The decision-making process is a procedure of identifying decision criteria, gathering information, and appraising alternative resolutions to aid choice. The process is enhanced when appropriate models are used in providing information to increases the probabilities that managers will make the best choice out of many alternatives (Al-Tarawneh, 2012). DMP was measured by decision-making steps, cost volume profit analysis information usefulness, and management efficiency. Previous results showed that little or no study had been conducted on the decision-making process of manufacturing SMEs in connection with profit planning. Therefore, the conclusion on the effect of DMS and pp2 is in doubt hence the subhypothesis 2 
$\mathbf{H}_{2}$ : Decision-making process has no significant effect on profit planning.

Top management support is an essential success factor in any project achievement (Young \& Jordan, 2008). This sub-variable is expected to boost the acceptance, application, and implementation of the result of the cost volume profit analysist, which might influence proper planning (Khan, Long, \& Iqbal, 2014). TMS was measured by the provision of adequate facilities, management attention to cost volume profit analysis, and effective reports implementation. To the best of the researcher's knowledge, the effect of TMS on pp3 has been omitted in the body of knowledge. Hence the formulation of sub-hypothesis 3

$\mathbf{H}_{3}$ : Top management support has no significant effect on profit planning.

\section{Cost Volume Profit Analysis}

The model for the study was specified as $\mathrm{PP}=f(\mathrm{CVPA})$. Where cost volume profit analysis covers AQE, DMP, and TMS as a function of PP covering pp1, pp2, and pp3. To test the effect of cost volume profit analysis on profit planning, hypothesis 4 was proposed.

$\mathbf{H}_{4}$ : Cost volume profit analysis has no significant effect on profit planning

\section{Cost Volume Profit Analysis Conceptual Framework}

Based on the omissions in the body of knowledge, the current study now proposes a new conceptual framework, which suggests that there is a relationship between cost volume profit analysis application and profit planning in manufacturing SMEs. Figure 4 shows the link between cost volume profit analysis and its sub-variables and profit planning. 


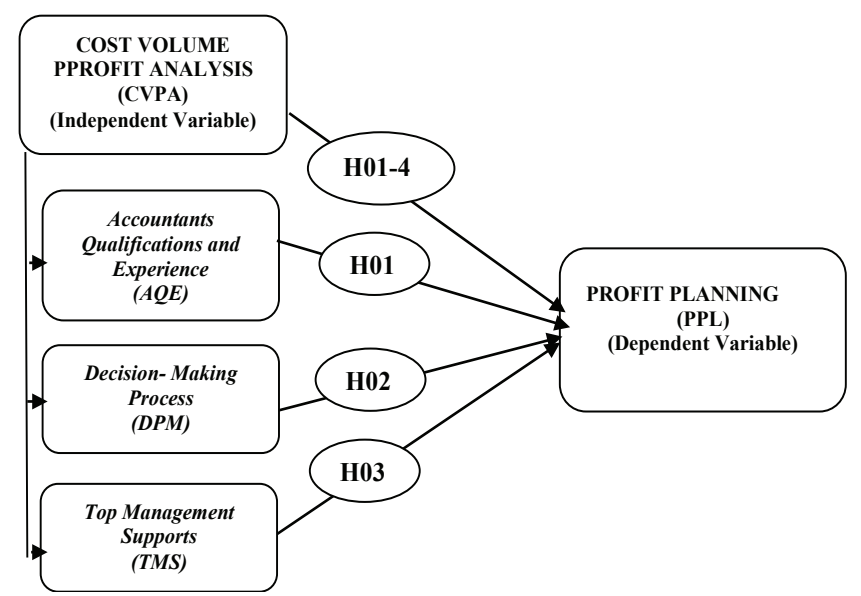

Figure 4: Conceptual Framework of CVPA and Profit Planning

\section{RESEARCH METHODS}

A cross-sectional survey research design was used to measure the respondents' options elicited through copies of the questionnaire. It also helped the researcher to describe the characteristics of the phenomenon in the data analyzed (Shields \& Rangarajan, 2013; Okpala, Mlanga, Nwajiuba, Osanebi, \& Ezemoyih, 2019). The study population comprised all small and medium-sized manufacturers in Nigeria. The study employed a two-stage judgmental sampling technique. In the first stage, the research adopted a snowball sampling technique due to non-availability of the exhaustive list and adequate information about the manufacturing SMEs in Nigeria. This technique enabled referrals among members of the subsector. The second stage of the sample was the adoption of a simple random sampling technique. The selection consisted of twenty-three (23) small-sized firms with eight (8) each and twenty-seven (27) medium-sized enterprises with thirty-two (32) staff each. A total of fifty (50) manufacturing SMEs with one million, and forty-eight (1048) respondents were selected randomly from the two strata. The variation in the size of respondents between small and mediumsized firms was due to the difference in the number of staff employed by two categories of the organizations. The criteria for the researcher's choice of respondents were based on the following: The selected firms must be (i) located in Lagos, South-western Nigeria due to SMEs concentration and 
for accessibility, and (ii) operates within the textile, chemical, food and beverage, and plastic subsectors. The selected respondent must (i) be senior staff, and (ii) have a minimum of three years' cumulative work experience in manufacturing SMEs. The result of the sampled population obtained is shown in Table 1.

Table 1: Population Make Up the Definition

\begin{tabular}{clccc}
\hline S/N & \multicolumn{1}{c}{ SMEs } & $\begin{array}{c}\text { No of } \\
\text { firms }\end{array}$ & No of staff & Participants \\
\hline 1 & Small size manufacturers & 23 & 8 from each firm & 184 \\
2 & Medium size manufacturers & 27 & 32 from each firm & 864 \\
\hline & Total & $\mathbf{5 0}$ & & $\mathbf{1 0 4 8}$ \\
\hline
\end{tabular}

Source: Researchers; Fieldwork (2019)

The structured instrument consisted of questions partly adapted and those generated by the researcher. The instrument was divided into five sections. Section A is for the respondents' demographic profile, while sections $\mathrm{B}$ to $\mathrm{E}$ were for data relating to the constructs. The instrument contained eighteen (18) close-ended questions on the variables with seven-point Likert scale response: very low (1); low (2); slightly low (3); average (4); slightly high (5); high (6); very high (7). A pilot study exercise was conducted to assess the level of participants' understanding of the questions. It was also used to check the relevance of the questions and the level of respondents' interest (Creswell \& Creswell, 2019). Copies of the questionnaire were administered to forty-five (45) respondents from nine companies with the same characteristics of the population. A total of twenty-three (23) valid copies were received and analyzed, representing a $51 \%$ response rate.

Face validity was established by two professors of management accounting who read through and made corrections in terms of wording, layout, and style. The logical validity test was to ensure that participants can answer the questions. The instrument was afterwards confirmed. Content validity was tested to assess the extent to which the measure represented all facets of the construct (Cozby, 2003). Confirmatory factor analysis was used to test the instrument and proposed variable indicators had a significant factor loadings. The average variance extracted showed values between .586 and .659 with $\mathrm{AVE}=609>.05$. This confirmed that the variables were valid and could be used for further analysis. Cronbach's alpha coefficient was 
used to test the reliability of the instrument for data collection. The result indicated $\mathrm{R}_{\mathrm{c}}$ between .619 and .700 with $\mathrm{R}_{\mathrm{c}}=.660>.05$, which established the internal consistency and reliability of the instrument. The results are presented in Table 2

Table 2: Result of Construct Validity and Reliability Test

\begin{tabular}{lccc}
\hline \multicolumn{1}{c}{ Items } & No. Questions & Validity & Reliability \\
\hline $\begin{array}{l}\text { Accountants qualifications and } \\
\text { experience }\end{array}$ & 4 & 0.586 & 0.643 \\
\hline Decision-making process & 4 & 0.625 & 0.619 \\
\hline Top management support & 5 & 0.574 & 0.700 \\
\hline Profit planning & 5 & 0.659 & 0.679 \\
\hline Average variance extracted & $\mathbf{1 8}$ & $\mathbf{0 . 6 0 9}$ & $\mathbf{0 . 6 6 0}$ \\
\hline
\end{tabular}

Source: Researchers Fieldwork (2019)

Descriptive statistics and regression techniques were used for data analysis at a 5\% level of significance. Percentage, frequency, and mean scores were used to describe the average respondents' opinions of each of the constructs. A confirmatory factor analysis was also used to endorse those statements that explained cost volume profit analysis as a tool for profit planning. The regression analysis was adopted to examine the effect of cost volume profit analysis on profit planning in the manufacturing 'SMEs. The co-linearity test conducted indicated that the predictor relationships with the outcome variable met the linear regression expectations.

\section{Regression Model}

To test null hypotheses formulated in the above subsection, the regression model was specified as follows:

$$
\begin{aligned}
& \text { H01: } \mathrm{ppd} 1 \mathrm{smm}=\beta_{0}+\beta_{1}\left(\mathrm{QEA}_{\mathrm{cvpa}}\right)+\varepsilon_{1} \ldots \ldots \text { [Model 1] } \\
& \text { H02: } p \text { pd2smm }=\beta_{0}+\beta_{2}\left(\mathrm{DMP}_{\text {cvpa }}\right)+\varepsilon_{2} \ldots \ldots \text {. [Model 2] } \\
& \text { H03: } p \text { pd3smm }=\beta_{0}+\beta_{3}\left(\mathrm{TMS}_{\mathrm{cvpa}}\right)+\varepsilon_{3} \ldots \ldots \text { [Model 3] } \\
& \text { H04: PP }=\beta_{0}+\beta_{1}(\mathrm{CVPA})+\varepsilon \ldots \ldots \ldots \ldots \ldots . .[\text { Model 4] }
\end{aligned}
$$


Where:

CVPA $=$ Cost Volume Profit Analysis covering AQE, DMP, and TMS $\mathrm{AQE}=$ Accountants' qualifications and experience

$\mathrm{DMP}=$ Decision-making process

TMS $=$ Top management support

Previous studies showed that SMEs in Nigeria faced various challenges (Ololube \& Uzorka, 2008; Ebiringa, 2011; Kadiri, 2012; Abeh, 2017). According to Anochie, Ude, and Egbo (2015), these setbacks have resulted in inadequate investment with a chain of effects, which hinders the acquisition of modern plant and machinery to produce quality products at a low cost, inability to employ qualified and experienced accountants, and difficulty in providing major work facilities. The SMEs' weak management team composition and undue family involvement have also adversely affected managerial capacity, planning, and decision-making quality (Asikhia, 2016). Based on these findings, the a priori expectation indicates that the effect of the sub-variables of the independent on profit planning may be less than zero and can be mathematically expressed as:

$$
\mathrm{AQE}<0, \mathrm{DMP}<0, \mathrm{TMS}<0
$$

\section{RESULTS AND FINDINGS}

One thousand and forty-eight copies of questionnaires were distributed to eligible respondents. A total of 202 participants failed to return the copies of their survey. The 846 copies returned were subjected to a screening process. The elimination procedure resulted in the rejection of 132 invalid copies, while 714 useable copies representing a $68 \%$ response rate was achieved. This rate was considered good enough judging from the rate achieved in similar previous studies such as Okpala (2012 with 55\%; Alnasser et al. (2014) with 69\%; and Adesina, Ikhu-Omoregbe, \& Kehinde (2015) with $72 \%$. 


\section{Demographic Characteristics}

The demographic profile in Table 3 shows that 344 respondents representing $48 \%$ were in the $31-40$ years age group, while 329 of the respondents hold a $\mathrm{BSc} / \mathrm{HND}$, constituting $46 \%$ of the entire respondents. 221 , representing $31 \%$ of the respondents, were certified with various accounting bodies signifying that most of the management accountants were professionally qualified. 255 , of the respondents, had between 1 and 5 years' work experience in their present organization constituting 36\%, while 344 , representing $48 \%$ had between 11 - and 20 -years' total work experiences. 300 respondents were lower managers, representing 53\% showing the usual management hierarchy pattern of a wider-base and narrow-top. Demographic Information showed that manufacturing SMEs in Nigeria have a mature workforce who have adequate academic and professional qualifications, and cognate work experience. However, there is high labour turnover within the subsector. This result is shown in Table 3

Table 3: Demographic Information

\begin{tabular}{|c|c|c|c|}
\hline Items & & $\begin{array}{l}\text { Frequency } \\
\text { (No) }\end{array}$ & $\begin{array}{c}\text { Percentage } \\
\%\end{array}$ \\
\hline \multirow{5}{*}{ Age } & $20-30$ & 103 & 14 \\
\hline & $31-40$ & 344 & 48 \\
\hline & $41-50$ & 153 & 21 \\
\hline & $51-60$ & 87 & 12 \\
\hline & $60+$ & 27 & 04 \\
\hline \multirow{5}{*}{ Academic qualification } & School Certificate & 163 & 23 \\
\hline & OND & 144 & 20 \\
\hline & B.Sc./HND & 329 & 46 \\
\hline & MSc/MBA & 60 & 08 \\
\hline & Ph.D./DBA/DSc & 18 & 03 \\
\hline \multirow{3}{*}{ Professional qualification } & ACA/CIMA/ACCA & 221 & 31 \\
\hline & COREN/Others & 193 & 27 \\
\hline & Uncertified & 300 & 42 \\
\hline \multirow{5}{*}{$\begin{array}{l}\text { Work experience in the } \\
\text { present firm }\end{array}$} & $1-5$ years & 255 & 36 \\
\hline & $6-10$ years & 160 & 22 \\
\hline & $11-15$ years & 126 & 18 \\
\hline & $16-20$ years & 105 & 15 \\
\hline & $20+$ years & 68 & 01 \\
\hline
\end{tabular}




\begin{tabular}{llcc}
\hline Items & Frequency & $\begin{array}{c}\text { Percentage } \\
\text { (No) }\end{array}$ & $\begin{array}{c}\text { Por } \\
\text { Length service }\end{array}$ \\
& $1-10$ years & 170 & 24 \\
& 11-20 years & 344 & 48 \\
Managers grade & 21+ years & 200 & 28 \\
\hline \multirow{3}{*}{ Lower } & 380 & 53 \\
& Middle Manager & 182 & 25 \\
& Top manager & 152 & 21 \\
\hline
\end{tabular}

Sources: Primary data (2019)

\section{Descriptive Statistics}

The seven-point interval scale was reclassified into three major scales as follows: $1-3=$ insignificant, $3.5=$ average, $5-7=$ significant as used by Okpala (2017). The reclassification was to assist in the interpretation of the results. Data were analyzed to identify the statements with mean scores equal to or higher than 3.50. The first objective was to establish whether accountants with adequate qualifications and experience have a relationship with profit planning. Items B1, B2, B3, and B4 were used to track this objective. The results show mean scores of $6.30,5.51,4.87$, and 6.12, respectively, with an average of $5.70>3.5$. The second objective was to find out whether the decision-making process based on the cost volume profit analysis model aids the profit planning of manufacturing SMEs. Items $\mathrm{C} 1$, $\mathrm{C} 2, \mathrm{C} 3$, and C4 were used to measure this objective. The mean scores of $5.22,5.51,6,23$, and 5.29, respectively with, an average of $5.55<3.5$. The third objective was to assess whether top management support of CVPA application in manufacturing SMEs relates to profit planning. Items D1, D2, D3, D4, and D5 were used to achieve this objective. The means scores of $5.42,5.50,5.61,6.13$, and 5.48, respectively with, an average of 5.63> 3.5. The descriptive statistics provided the answer to the research questions and enabled us to achieve the research objectives. This relationship is further tested in Hypothesis 1 to 4 of the study. Table 4 shows the statistics result. 
Table 4: Descriptive Statistics for Cost Volume Profit Analysis

\begin{tabular}{|c|c|c|c|c|c|c|}
\hline Code & Item & $\mathbf{n}$ & Min & Max & Mean & $\begin{array}{l}\text { Std. } \\
\text { Dev. }\end{array}$ \\
\hline B1 & $\begin{array}{l}\text { Accountants have a minimum } \\
\text { qualification. }\end{array}$ & 714 & 1 & 7 & 6.30 & .572 \\
\hline B2 & $\begin{array}{l}\text { Accountants are professionally } \\
\text { certified }\end{array}$ & 714 & 1 & 7 & 5.51 & .682 \\
\hline B3 & $\begin{array}{l}\text { Accounting staff have adequate } \\
\text { experience }\end{array}$ & 714 & 1 & 7 & 4.87 & 1.01 \\
\hline B4 & $\begin{array}{l}\text { Staff have adequate knowledge } \\
\text { of CVPA }\end{array}$ & 714 & 1 & 7 & 6.12 & .891 \\
\hline C1 & $\begin{array}{l}\text { Step to step decision making is } \\
\text { adopted }\end{array}$ & 714 & 1 & 7 & 5.22 & .721 \\
\hline $\mathrm{C} 2$ & CVPA aids informed decision & 714 & 1 & 7 & 5.51 & .812 \\
\hline C3 & $\begin{array}{l}\text { CVPA is a useful tool to } \\
\text { management }\end{array}$ & 714 & 1 & 7 & 6.23 & .902 \\
\hline $\mathrm{C} 4$ & $\begin{array}{l}\text { CVPA boosts Management } \\
\text { efficiency }\end{array}$ & 714 & 1 & 7 & 5.24 & .765 \\
\hline D1 & $\begin{array}{l}\text { Top management supports } \\
\text { CVPA application }\end{array}$ & 714 & 1 & 7 & 5.42 & .881 \\
\hline D2 & $\begin{array}{l}\text { Management implements result } \\
\text { of CVPA }\end{array}$ & 714 & 1 & 7 & 5.50 & .743 \\
\hline D3 & $\begin{array}{l}\text { CVPA helps managers in their } \\
\text { duties }\end{array}$ & 714 & 1 & 7 & 5.61 & .814 \\
\hline D4 & $\begin{array}{l}\text { Managers pay attention CVPA } \\
\text { report }\end{array}$ & 714 & 1 & 7 & 6.13 & 1.17 \\
\hline D5 & $\begin{array}{l}\text { Facilities are provided for CVPA } \\
\text { implementation }\end{array}$ & 714 & 1 & 7 & 5.48 & .794 \\
\hline
\end{tabular}

Source: Primary data (2019)

\section{Confirmatory Factor Analysis}

Confirmatory factor analysis was conducted to endorse statements, which explained the cost volume profit analysis as a tool for profit planning. Keiser-Meyer-Olkin (KMO) and Bartlett's tests were used to evaluate the appropriateness of the data for factor analysis based on sample size adequacy. Kaiser (1974) noted that these tests are performed to ensure that factor analysis produced varied and reliable factors. The value of KMO and Bartlett's tests is between 0 and 1 (Field, 2009). Also, the sampling adequacy 
is measured based on the following rule: less than $0.5=$ Unacceptable; 0.5-6.9=Average; 0.7-7.9=Good; 0.8-8.9 Great; and 0.9-1=Superb (Bartlett, 1954). The results indicated that the KMO values for the accountants' qualifications and experience were .724, the decision-making process was .611 , whereas top management support was .710 . Bartlett's test of sphericity indicated statistical significance for all scales [p-value of 0.00 for each scale]. Table 5 shows the CFA result.

Table 5: Confirmatory Factor Analysis for CVPA

\begin{tabular}{|c|c|c|c|}
\hline Item & AQE & DMP & TMS \\
\hline Accountants have minimum qualification. & .678 & & \\
\hline Accountants are professionally certified & .724 & & \\
\hline Accounting staff have adequate experience & .863 & & \\
\hline Staff have adequate knowledge of CVPA & .761 & & \\
\hline Step to step decision making is adopted & & .692 & \\
\hline CVPA aids informed decision & & .759 & \\
\hline CVPA is a useful tool to management & & .709 & \\
\hline Management efficiency is boosted by CVPA & & .712 & \\
\hline Top management supports CVPA application & & & .821 \\
\hline Management implements result of CVPA & & & .793 \\
\hline CVPA helps managers in their duties & & & .785 \\
\hline Managers pay high premium to CVPA report & & & .769 \\
\hline Facilities are provided to implement CVPA & & & .876 \\
\hline Eigen values & 3.026 & 3.652 & 4.044 \\
\hline Percentage variance & 22.654 & 18.789 & 23.453 \\
\hline Cumulative percentage & 22.654 & 41.443 & 64.896 \\
\hline
\end{tabular}

Extraction Method: Principal Component Analysis. Rotation Method: Varimax with Kaiser Normalization Source: Primary data (2019) 


\section{Karl Pearson Product Moment Correlation Statistical Analysis}

To ensure the robustness of the descriptive statistics, the Pearson product-moment correlation statistical analysis method was used to confirm the degree of the linear relationship between the variables in this study. The result of $\mathrm{H} 01$ shows $R=.769, P=.000$, indicating an average positive and significant relationship between the variables. H02 result indicated that $R=.677, P=.010$ shows that the decision-making process and profit planning are positively and significantly related. The result of $\mathrm{H} 03$ revealed that $R=.718, P=.000$, which indicated that the relationship between top management support and profit planning is positive and significant. These results of the PPMC agreed with descriptive statistics. These results are shown in Table 6.

Table 6: Correlation Matrix

\begin{tabular}{llcccc}
\hline & & PP & AQE & DMP & TMS \\
\hline AQE & Pearson correlation & $.769^{*}$ & 1 & & \\
& Sig (1 tailed) & .000 & .000 & & \\
& $\mathrm{~N}$ & 714 & 714 & & \\
\hline DMP & Pearson correlation & $.677^{* *}$ & $.669^{*}$ & 1 & \\
& Sig (1 tailed) & .001 & .003 & .002 & \\
& $\mathrm{~N}$ & 714 & 714 & 714 & \\
\hline TMS & Pearson correlation & $.713^{* *}$ & $.693^{* *}$ & $.722^{* *}$ & 1 \\
& Sig (1 tailed) & .000 & .000 & .000 & .000 \\
& $\mathrm{~N}$ & 714 & 714 & 714 & 714 \\
\hline
\end{tabular}

${ }^{*}$ Correlation is significant at the 0.05 level (two-tailed); ${ }^{\star *}$ correlation is significant at the 0.01 level (two-tailed). PP=profit planning; $\mathrm{AQE}=$ Accountant qualification and experience; $\mathrm{DMP}=$ Decision making process; TMS= Top management support. Source: Primary data (2019).

\section{The Regression Analysis Results}

Model 1 result: In Table $7 \mathrm{a}, R=.766$ indicates that qualified and experienced accountants have an average positive effect on profit planning. The $R^{2}=.732$ confirms that AQE is responsible for $73 \%$ of the deviation in pp1 in manufacturing SMEs. In Table $7 b$, the effect AQE on pp1 is significant at $\mathrm{P}$-value $=.000<.05$. The linear equation can be stated as $\mathrm{AQE}=2.890+.349(\mathrm{pp} 1)$. This equation means that a unit change in $\mathrm{AQE}$ would drive about a $40 \%$ increase in pp1. 
Model 2 result: $R=.620$ shows that the decision-making process (DMP) has an average positive effect on profit planning, as shown in Table 7a Model 2. The $R^{2}=.612$ shows that DMP accounts for $47 \%$ variation in the pp2 in manufacturing SMEs. DMP effect on pp2 is significant at $\mathrm{P}$-value $=.001<.05$ as shown in Table $7 \mathrm{~b}$. The linear equation of DMP and pp2 can be expressed as DMP $=2.890+0.298(\mathrm{pp} 2)$, which inferred that a change in DMP would boost an upturn of $30 \%$ in pp2.

Model 3 result: In Table 7a Model 3, $R=.723$ indicates that top management support (TMS) of CVPA has an average positive effect on profit planning (pp3). The $R^{2}=.714$ shows that TMS is responsible for $51 \%$ of the disparity in the pp3 in manufacturing SMEs. The relationship between the variables is significant at $\mathrm{P}$-value $=.002<.05$. The linear equation can be expressed as TMS $=2.890+0.331$ (pp3), which suggests that a unit change in TMS would compel a $33 \%$ increase in pp3.

Model 4 result: In Table $7 \mathrm{a}$, the overall $R$-value $=.774$, which indicates that CVPA has a strong positive effect on profit planning (PP). The $R^{2}=752$ shows that CVPA is responsible for a $75 \%$ change in the PP in manufacturing SMEs. The linear equation expressed as $\mathrm{CVPA}=2.890+0.567(\mathrm{PP})$, implies that a unit change in CVPA would compel 57\% improvements in PP.

Table 7a: Model Summary of CVPA

\begin{tabular}{lcccccc}
\hline Constructs & Model & $\mathbf{R}$ & $\mathbf{R}^{2}$ & Adjusted $\mathbf{R}^{2}$ & $\begin{array}{c}\text { Standard Error } \\
\text { of Estimate }\end{array}$ & $\begin{array}{c}\text { Durbin- } \\
\text { Watson }\end{array}$ \\
\hline AQE & 1 & .766 & .732 & .721 & .132 & 1.023 \\
DMP & 2 & .620 & .672 & .642 & .101 & 1.321 \\
TMS & 3 & .723 & .714 & .675 & .110 & 1.498 \\
CVPA & 4 & .774 & .752 & .686 & .089 & 1.475 \\
\hline
\end{tabular}

Source: Primary data (2019) 
Table 7b: ANOVA Results of CVPA

\begin{tabular}{llccccc}
\hline Variable & Sum of & $\begin{array}{c}\text { Suares } \\
\text { squa }\end{array}$ & $\begin{array}{c}\text { Mean } \\
\text { sq. }\end{array}$ & f & Significance \\
\hline Accountants & Regression & 2.900 & 1 & 2.900 & & \\
qualification & Residual & 182.116 & 713 & 0.255 & 5.773 & .000 \\
$\begin{array}{l}\text { and experience } \\
\text { (AQE) }\end{array}$ & Total & 185.016 & 714 & & & \\
\hline \multirow{2}{*}{$\begin{array}{l}\text { Decision making } \\
\text { process (DMP) }\end{array}$} & Regression & 4.200 & 2 & 2.100 & &. \\
& Residual & 188.402 & 712 & 0.265 & 2.432 & .001 \\
Top managemental & 192,602 & 714 & & &. \\
support (TMS) & Regression & 6.499 & 3 & 2.166 & & \\
& Residual & 191.322 & 711 & 0.269 & 5.655 & .000 \\
CVPA & Regression & 9.222 & 4 & 2.306 & & \\
\hline & Residual & 196.448 & 710 & 0.276 & 6.005 & .000 \\
\hline
\end{tabular}

Table 7c: Results of the Coefficients Value of Cost Volume Profit Analysis

\begin{tabular}{lcccccc} 
& & \multicolumn{2}{c}{$\begin{array}{c}\text { Unstandardized } \\
\text { coefficients }\end{array}$} & $\begin{array}{c}\text { Standardized } \\
\text { coefficients }\end{array}$ & & \\
\cline { 3 - 6 } & $\mathbf{n}$ & $\mathbf{B}$ & $\begin{array}{c}\text { Standard } \\
\text { Error }\end{array}$ & $\boldsymbol{\beta}$ & & Significance \\
Constant & & 2.890 & & & 25.346 & .000 \\
AQE & 714 & .349 & .098 & .766 & 1.998 & .001 \\
DMP & 714 & .298 & .108 & .620 & 1.890 & .000 \\
TMS & 714 & .331 & .117 & .723 & 1.922 & .000 \\
CVPA & 714 & .567 & .167 & .774 & 1.876 & .000 \\
\hline
\end{tabular}

Source: Primary Data (2019)

The standard errors (SEs) of .132, .101, 110, and .089 respectively in model 1 to 4, for the four hypotheses in Table 7a, confirms how well and accurate an estimated coefficient was designed. The SEs are low, showing that the study coefficient was fairly estimated. Also, in Table 7a, the DurbinWatson statistics of $1.023,1.321,1.489$, and 1.475 of the residuals, between 0 and 2, suggests that there is the presence of positive autocorrelation. Since all DW scores were higher than the $\mathrm{R}^{2}$ in the four models (.701, $.587,675$, and .686), the result obtained is considered valid and a sign of a 
reasonable degree of the model specifications. The AQE, DMP, and TMS percentage that was not explained measured by $\left(1-\mathrm{R}^{2} \%\right)$ were $27 \%, 39 \%$, $29 \%$, and $25 \%$. The unexplained percentages may be due to other factors that were not included in this model. The significance of the model at .05 level was confirmed by the t-statistics of $1.998,1.890,1.922$, and 1.876 . The result obtained showed that the effect of the proxies of the independent variable on profit planning is greater than zero (AQE $>0$; DMP $>0$; TMS $>0$ ). Therefore, the results opposed the a priori expectations. Based on the evidence available, the null hypothesis 1, 2, 3, and 4 were rejected, and the alternates not rejected. A summary of the hypotheses tested are presented in Table 8.

Table 8: Summary Results of Hypotheses Tested

\begin{tabular}{|c|c|c|c|c|c|c|c|}
\hline \multirow{2}{*}{$\mathrm{H} / \mathrm{N}$} & \multirow{2}{*}{$\begin{array}{l}\text { Statement of } \\
\text { Hypotheses }\end{array}$} & \multirow{2}{*}{$\mathbf{R Q}$} & \multicolumn{3}{|c|}{ Test Results } & \multirow{2}{*}{ Correlation } & \multirow{2}{*}{ Remarks } \\
\hline & & & $r$ & LS(x) & Inference & & \\
\hline 1 & $\begin{array}{l}\mathrm{H}_{0:} \text { Accountants } \\
\text { "qualification and } \\
\text { experience has no } \\
\text { significant effect on } \\
\text { profit planning }\end{array}$ & B1-B4 & .766 & 0.5 & $r>x$ & Average + & $\begin{array}{l}\text { Reject } \\
\text { HO }\end{array}$ \\
\hline 2 & $\begin{array}{l}\mathbf{H}_{0:} \text { Decision-making } \\
\text { process has no } \\
\text { significant effect on } \\
\text { profit planning. }\end{array}$ & C1-C4 & .620 & 0.5 & $r>x$ & Average + & $\begin{array}{c}\text { Reject } \\
\text { HO }\end{array}$ \\
\hline 3 & $\begin{array}{l}\mathbf{H}_{0} \text { Top management } \\
\text { support has no } \\
\text { significant effect on } \\
\text { profit planning }\end{array}$ & D1-D5 & .723 & 0.5 & $r>x$ & Average + & $\begin{array}{c}\text { Reject } \\
\text { H0 }\end{array}$ \\
\hline 4 & $\begin{array}{l}\text { CVPA has no } \\
\text { significant effect on } \\
\text { profit planning }\end{array}$ & B1-D5 & .761 & 0.5 & $r>x$ & Strong + & $\begin{array}{c}\text { Reject } \\
\text { H0 }\end{array}$ \\
\hline
\end{tabular}

Key: $\mathrm{H} / \mathrm{N}=$ hypotheses no., $\mathrm{RQ}=$ research questions, $\mathrm{LS}=$ level of significant, Infr. = inference

Source: Fieldwork 2019

\section{DISCUSSION}

The results confirmed that when qualified and experienced accountants with good knowledge of cost volume profit analysis are employed, data for planning is provided to enhance managerial efficiency in manufacturing SMEs. The positive and significant relationship between the variables in hypothesis 1 indicated that management pays attention to the caliber of accounting staff employed. This result agreed with Georgiev (2014), who 
concluded that there is a significant association between data generated by the cost-volume-profit analysis and profitability of an organization. The results of hypothesis 2 indicated that the cost volume profit analysis decisionmaking process in manufacturing SMEs encourages proper planning. This finding is in agreement with the report presented by previous studies. Dabor et al. (2013), who concluded that cost volume profit analysis provides management with information to make effective decisions. Also, Adesina et al. (2015), Ihemeje et al. (2015) and Kavitha (2018) concluded that the cost volume profit analysis technique is a well-considered decision-making tool in manufacturing firms. In hypothesis 3 , the finding indicated that there is a positive and significant relationship between top management support and profit planning in manufacturing SMEs. This result proved that when top management manufacturing SMEs support the cost volume profit analysis model, attention would be paid the reports, appropriate facilities provided, proper implementation of the report would be undertaken to plan and attain goals (Young \& Jordan, 2008; Khan et al., 2014). This result concurs with the findings of Obeta (2008), Dabor et al. (2013), Alnasser et al. (2014), Adesina et al. (2015), Ihemeje et al. (2015); Kavitha (2018).

\section{CONCLUSION, CONTRIBUTION AND RECOMMENDATIONS}

Previous studies reviewed indicated that manufacturing SMEs are faced with many challenges inhibiting profitability and survival. The objective of this study was to generate empirical evidence on the effect of CVPA on profit planning. This objective was accomplished through the opinions elicited from 714 senior staff of manufacturing SMEs in Nigeria based on the questionnaire administered. The result obtained shows that accurate cost volume profit analysis information is produced when the manufacturing SMEs employs accountants with appropriate qualifications and experience. It also indicates that reports produced from CVPA enhance the effectiveness of the management decision-making process. The method enables managers to make an optimal choice among various alternatives. Also, the implementation of the cost volume profit analysis report based on the top management support would aid the attainment of organizational profitability. 
The study contributed conceptually by proposing a new conceptual framework, which confirmed that there is a relationship between the application of cost volume profit analysis and profit planning in manufacturing SMEs. The theoretical contribution of this research is the confirmation of the relevance of the institutional theory and innovations theory of profits. Lastly, the study also contributed empirically by producing a practical result, which indicates that the relationship between the independent and the dependent variables is not only positive but significant.

The findings from this study generated a decision pattern for the management of manufacturing SMEs in Nigeria. The key findings from this study are summarized as follows: First, cost volume profit analysis is a reliable tool for profit planning, and the management of manufacturing SMEs should intensify its application. Second, there is a need for the management in manufacturing SMEs to employ high caliber accountants with appropriate experience and knowledge of cost volume profit analysis to assist in the production of data for profit planning. Third, accounting staff should be adequately motivated to reduce the extent of labour turnover in manufacturing SMEs. Fourth, the decision-making process should be streamlined for effectiveness. Fifth, top management of manufacturing SMEs needs to support the cost volume profit analysis model to enable adequate profit planning, determination of the margin of safety, and the achievement of the envisaged bottom-line.

The robustness of the data analysis was also seen in the use of the generalized method of movement (GMM). The GMM is a generic method for estimating parameters in statistical models. The technique was used to estimate the cross-sectional data to ascertain the properties of the study data. This exercise enabled the researchers to identify a suitable method to be used. The GMM panel estimation method was used to re-estimate all the models. All the results were the same under the assessment, although these results are not shown in this research paper. 


\section{LIMITATIONS AND SUGGESTION FOR FURTHER STUDY}

Despite the contributions and implications of this study, only a total population of 50 SMEs with 1048 participants were used among the thousands of SMEs in Nigeria. Also, dummy variables such as managerial efficiency, facilities, and market information were excluded. Due to these limitations, the results obtained from this study may vary if future researchers conduct further studies by using an expanded population and include the dummy variables. Therefore, we suggest that further research be carried out.

\section{REFERENCES}

Abdullahi, R. S. (2015). Mastering cost and management accounting ( $3^{\text {rd }}$ ed.). Kano: Sharif Mahir Investment Ltd.

Abdullahi, R. S., Sulaimon, B. A., Mukhtar, I. S., \& Musa, M. H. (2017). Cost-volume-profit analysis as a management tool for decision making in small business enterprise within Bayero University, Kano. IOSR Journal of Business and Management (IOSR-JBM), 19(2), 40-45.

Abeh, O. (2017). Entrepreneurship as key to socio-economic development: A study of selected small and medium scale enterprises in Delta State. Journal of Education and Society, 7(1), 90-102.

Adeniji, A. (2017). An insight into management accounting. Shomolu, Lagos: Value Analysis Consult.

Adesina, O. T., Ikhu-Omoregbe, S. \& Aboaba, K. O. (2015). Accounting information and profit Planning: The case of Nigeria listed manufacturing companies. European Journal of Accounting Auditing and Finance Research, 3(4), 86 - 97.

Agwu, M. O. (2014). Issues, challenges and prospects of small and medium scale Enterprises (SMEs) in Port-Harcourt City, Nigeria. European Journal of Sustainable Development, 3(1), 101-114. 
Akinsulire, O. (2017). Financial management ( ${ }^{\text {th }}$ ed.). Lagos: Ceemol Nigeria Ltd.

Alnasser, N., Shaban, O. S., \& Al-Zubi, Z. (2014). The effect of using break-even-point in planning, controlling, and decision making in the industrial Jordanian companies. International Journal of Academic Research in Business and Social Sciences, 4(5), 626-636.

Al-Tarawneh H. A., (2012). The main factors beyond decision making. Journal of Management Research, 4(1), 1-23.

Anochie, U. C., Ude, D. K., \& Egbo, V. O. (2015). Entrepreneurship and socio-economic development: The case of Nigeria. International Journal of Management Sciences Research Academy of Social Sciences, 6(7), 346-365.

Aremu, M. A., \& Adeyemi, S. A. (2011). Small and medium scale enterprises as a survival strategy for employment generation in Nigeria. Journal of Sustainable Development, Canadian Canter of Science and Education, 4(1), 200-206.

Asah, F., Fatoki, O. O., \& Rungani, E. (2015). The impact of motivations, personal values and management skills on the performance of SMEs in South Africa. African Journal of Economic and Management Studies, 6(3), 308-322.

Asikhia, O. U. (2016). SMEs, wealth creation and poverty alleviation in Nigeria. Journal of Economics and Behavioural Studies, 8(4), 17-31.

Ayozie, D. O., \& Farayola, S. O. (2005). The role of small scale industry in national development in Nigeria. International Journal of Business and common Market Studies, 3(2), 162-182.

Bartlett, M. S. (1954). A note on the multiplying factors for various Chisquare approximation. Journal of Statistics Society, 16(Series B), 296-298.

Chand, S. (2015). Benefits and limitations of break-even analysis | Financial Management. Retrieved 17, 2018, from Your Article Library: http:// 
www.yourarticlelibrary.com/financial-management/benefits-andlimitations-of-break-even-analysis-financial-management/29421

Chow, C, W. (1998). Using cost-volume-profit analysis as an integrative framework in cost management accounting courses. Journal of Accounting Education, 1(1), 137-139.

Clancy, D. K., \& Madison, T. F. (1997). Cost-volume-profit analysis and changing costs: Reconciling theory and practice. The Journal of Cost Analysis, 14(2), 89-108.

Cozby, P. C. (2003). Methods in behavioural research ( $7^{\text {th }}$ ed.). New York: McGraw-Hill.

Creswell J. W., \& Creswell J. D. (2019). Research design: Qualitative, quantitative, and mixed methods approaches ( $5^{\text {th }}$ ed.). USA: Sage Publication.

Dabor, E. L., Otalor, J. I., \& Erah, D. O. (2013). The cost-volume-profit model: A discuss. Accounting Frontiers, 4(2), 68-80.

Drury, C. (2008). Management and cost accounting. London: Booking Power Publishers.

Ebiringa, O. T. (2011). Entrepreneurship venturing and Nigeria's economic development: The manufacturing sector in focus. International. Journal of Business Management \& Economic Research, 2(6), 376-381.

Egbulonu K. G., \& Duru E. E. (2018). Diversifying the Nigerian economy: Role of small and medium scale enterprises. African Journal of Economics and Sustainable Development, 1(1), 33-46.

Eniola, A. A., \& Ektebang, H. (2014). SME firms' performance in Nigeria: Competitive advantage and its impact. International Journal of Research Studies in Management, 3(2), 75-86.

Etges, A. P., Calegari, R., Rhoden, M., \& Cortimiglia, M. (2016). Using cost-volume-profit to analyse the viability of implementing a new 
distribution center. Brazilian Journal of Operations \& Production Management, 13(1), 44-50.

Field, A. (2009). Discovering statistics using SPSS (3 $3^{\text {rd }}$ ed.). Thousand Oaks, CA: Sage Publication.

Georgiev, D. (2014), Application of cost-volume-profit analysis in the hotel industry (Based on survey data of high-ranking hotels in the North-East Region of Bulgaria). Izvestiya, 3, 48-60.

Glautier, M. W. E., Morris, D., \& Underdown, B. (2011). Accounting theory and practice. Harlow, England: Financial Times Prentice Hall.

Hilton, R., Maher, M., \& Selto, F. (2004). Cost management: Strategies for business decisions ( $3^{\text {rd }}$ ed.). Boston: McGraw-Hill/Irwin.

Ihemeje, J. C., Okereafor, G., \& Ogungbangbe, B. M. (2015). Cost-volumeprofit analysis and decision making in the manufacturing industries of Nigeria. Journal of International Business Research and Marketing, 1(1), 7-15.

Islam, M. A., Khan, M. A., Obaidullah, A. Z. M., \& Alam, M. S. (2011). Effect of entrepreneur and firm characteristics on the business success of small and medium enterprises (SMEs) in Bangladesh. International Journal of Business and Management, 6(3), 289-298.

Jhingan, M. L. \& Stephen, J. K. (2007). Managerial economics ( ${ }^{\text {rd }}$ ed.). Delhi: Vrinda Publications.

Kadiri, I. B. (2012). Small and medium scale enterprises and employment generation in Nigeria: The role of finance. Kuwait Chapter of Arabian Journal of Business and Management Review, 1(9), 79-93.

Kaiser, H. F. (1974). An index of factorial simplicity. Psychometrika, 39, 31-36.

Kavitha, R. (2018). Cost volume profitability analysis: An empirical study with reference to Salem Steel Authority of India Limited (SAIL). 
Tamilnadu. International Journal of Business and Management Invention, $7(5$ Ver. II), 46-51.

Kee, R. (2007). Cost-volume-profit analysis incorporating the cost of capital. Journal of Managerial Issues, 19(4), 478-493.

Khan, S. U. R., Long, C. S., \& Iqbal, S. M. J. (2014). Top management support, a potential moderator between project leadership and project success: A theoretical framework. Research Journal of Applied Sciences, Engineering and Technology, 8(11), 1373-1376.

Kodjo, S. N. (2004). Decision accounting for managers. Enugu: Oketek Publishers.

Lucey, T. L. (2003). Management accounting (5 $5^{\text {th }}$ ed.). London: Thomson Learning Publisher.

Lulaj, E., \& Iseni, E. (2018). Role of analysis CVP (Cost-Volume-Profit) as important indicator for planning and making decisions in the business environment. European Journal of Economics and Business Studies, 4(2), 99-114.

Makate, C., Makate, M., Siziba, S., \& Sadomba, Z. (2019). The impact of innovation on the performance of small-to-medium informal metaltrade enterprises in Zimbabwe. Cogent Business and Management, 6(1), 1625095.

Ndaliman, M. B., \& Suleiman, U. Y. (2011, June). An economic model for break-even analysis. Paper presented at the $2^{\text {nd }}$ International Conference on Mechanical and Manufacturing Engineering (ICME 2011).

Nwachukwu, C. C. (2004). Management: Theory and practice. Onitsha: Africana First Publishers Limited.

Obeta, N. J. (2008). The effectiveness of cost volume profit analysis in manufacturing industries: A case study of three selected companies (Unpublished master thesis). Department of Accounting, Faculty of Business Administration, Enugu Campus, Nigeria. 
Ogunode, P. O., Abereola, S. N., \& Oloyede, A. O. (2020). Entrepreneurship marketing and performance of SMEs in Nigeria. International Journal of Small Business and Entrepreneurship Research, 8(1), 39-52.

Okpala, K. E. (2012). Venture capital and the emergence and development of entrepreneurship: A focus on employment generation and poverty alleviation in Lagos State. CSCanada: International Business \& Management, 5(2), 134-141.

Okpala, K. E. (2017). Strategic budgetary system and infrastructure development of the power sector in Nigeria, 1981 - 2015. (Unpublished Ph.D. thesis), Department of Business Administration and Marketing of Babcock Business School.

Okpala, K. E., Adegbola, D., \& Afolabi, T. S. (2018). Management accounting information system and effective business decisions: An evaluation of quoted FMCG manufacturing firms. IMSU Business \& Finance Journal, 161-174.

Okpala, K. E., Mlanga, S., Nwajiuba, A. O., Osanebi, C. \& Ezemoyih, C. M. (2019). Producer's make or buy decision and business shutdown: An evaluation of choice in textile industry. Cogent Business \& Management, 6, 1-19.

Ololube, N. P., \& Uzorka, M. C. (2008). Introduction to entrepreneurship: A practical. Port Harcourt, Nigeria: Emhai Books.

Oyerogba, E. O., Solomon, A. Z., Olaleye, M. O., \& Adesina, T. O. (2014). Cost management practices and firm's performance of manufacturing organizations. International Journal of Finance and Economics, 6(6), 234-239.

Penrose, E. T. (1959). The theory of the growth of the firm. Oxford: Basil Blackwell.

Rijkers, B., Arouri, H., Freund, C., \& Nucifora, A. (2014). Which firms create the most jobs in developing countries? Evidence from Tunisia. (Policy Research Working Paper No. 7068). World Bank Group, Washington, 
DC. World Bank. Retrieved from https://openknowledge.worldbank. org/handle/10986/20514.

Schumpeter, J. A. (1934). The theory of economic development. Cambridge: Harvard University Press.

Shields, P. M, \& Rangarajan, N. (2013). A playbook for research methods: Integrating conceptual frameworks and project management. New Forums Press.

Stefan, D. (2012). Developing a cost-volume-profit model in production decision system based on MAD real options model. Procedia Economics, 3, 350-354.

Young, R., \& Jordan, E. (2008). Top management support: Mantra or necessity? International Journal of Project Management, 26(7), 713725 . 